\title{
Online Learning at Early Pandemic Situation: Grassroots Voices
}

\section{Mushoffan Prasetianto1*, Rizkiana Maharddhika², Hafida Ruminar ${ }^{3}$, Dian Islami Prasetyaningrum ${ }^{4}$}

\author{
${ }^{1}$ Department of Agronomy, University of Brawijaya, Malang, Indonesia \\ ${ }^{2,4}$ Department of Socio-economics, University of Brawijaya, Malang, Indonesia \\ ${ }^{3}$ Department of Pest and Plant Disease, University of Brawijaya, Malang, Indonesia \\ *e-mail: m.prasetianto@ub.ac.id
}

\begin{abstract}
The advent of the COVID-19 pandemic reconfigured several aspects of life, one of which is education. A study on grassroots voices on online learning is a dearth of. Therefore, a present study was addressed to uncover teachers' and students' voices in online learning. Questionnaires and interviews were employed to garner data. 233 students and 30 teachers' responses from questionnaires were obtained. The interviews were conducted to obtain in-depth data. The data were interpreted descriptively. The results showcased that students' voices on the ease of GC and GC performance were positive, yet institution support was not maximally implemented. Simultaneously, the teachers' voices on the ease of GC, the performance of GC, and the supports of institution were positive. In a nutshell, teachers and students have a positive impression of online learning. Their positive impression comes from the ease of the online platform operation, the online platform's good performance, but student views that the institutional support is not maximally implemented. The ease of using online platforms should be considered in choosing one of the various online platforms available. The online platform features are not complicated for students and teachers to easily operationalize the online platform and support teaching and learning activities such as delivering materials, assigning tasks, submitting a task, and assessing tasks.
\end{abstract}

Keywords: Pandemic, Online Learning, Google Classroom

\section{Introduction}

The advent of the COVID-19 pandemic reconfigured several aspects of our life, one of which is education. The pandemic reshaped teaching and learning aspects (Yi \& Jang, 2020). A course set for face-to-face was re-planned online. Several countries decided to regulate the lockdown policy, e.g., stayed at home, did self-isolation if needed, even worked and studied from home to prevent the spread of the virus. Consequently, online learning is exerted. For educators, it is a challenge because of a sudden transformative learning modality. Nevertheless, the challenge enabled teachers more creative (Yi \& Jang, 2020). They need to adapt to the online environment, which is possibly unfamiliar for some of them. Educators have an extra task to keep the learning process going and ensure that the students well-received the knowledge given.

Fortunately, the emergence of new technologies, such as internet, provides teachers with various online platforms. The online platforms used were Baidu Post Bar, Facebook, Google Docs, Piazza (Neumann \& Kopcha, 2019; Ruthotto et al., 2020; Shu \& Gu, 2018; Ulla \& Perales, 2020). Teachers are able to utilize online discussion to enhance learner's participation and interaction (Ke, 2013; Ruthotto et al., 2020; Zheng \& Warschauer, 2015). In addition, the internet offers a plethora of resources in which teachers select what best for their learners. Across several ways, the advent of online courses had inspired higher education lecturers to think more intensely than ever about how their students learn and communicate with their resources. Online courses make lecturers rethink how to design materials that the students can learn effectively. Online teaching and learning have two types of instruction: synchronous and asynchronous. Asynchronous communication as a written form while synchronous as real-time communication (Straub \& Vasquez, 2016). Those

\footnotetext{
${ }^{*}$ Corresponding author.
}

Received October 25, 2020; Accepted March 18, 2021; Available online September 25, 2021

Copyright @ 2021 by Author. Published by Universitas Pendidikan Ganesha.

Jurnal Pendidikan Indonesia (JPI) | 570 
instructions (synchronous and asynchronous) offer students to interact with other students with different cultural backgrounds. Students could exchange information and be free to choose how to learn.

Online learning is often used to write either collaborative writing or give feedback on an article. Students felt that online collaborative writing was effective with various procedures (Limbu \& Markauskaite, 2015). Therefore, the existence of a lecturer in online learning is still needed in order to vary the learning procedure. Some researches on the factors that affect online learning performance had also been conducted. The level of e-learning tool acceptance among students, particularly in developing countries revealed that the acceptance of e-learning services is influenced by three critical things: teacher preparation, independent learning, and a feeling of self-efficacy (Valencia-Arias et al., 2019). After investigating some students at three universities in Colombia, these three variables have been concluded. However, this has to consider the constraints of technical access and online accessibility faced by growing developing countries. Responding to the pandemic situation, Indonesia government decided a similar educational system regulation by shifting face-toface (offline) into an online learning or virtual classroom. The teacher used various online platforms (Atmojo \& Nugroho, 2020), and the second-highest of the online platform is Google Classroom (Purwanto et al., 2020). Google Classroom (hereafter, GC) provides in-class-like activities, e.g., assigning assignments, evaluating the assignment, uploading materials, having a discussion, and giving feedback. GC is an online academic platform in which teachers can conduct their teaching in an online environment. Google classroom is a paperless system for educational purposes.

Several previous studies have been conducted on virtual classroom or online learning. First study compared a virtual and traditional classroom for medical students in a specific radiology lesson (Morice et al., 2020). Their findings revealed that there were no noticeable differences between virtual and traditional classroom. Second study used Facebook as their virtual classroom and found that Facebook helps to engage the students on the path of personal development (Milošević et al., 2015). Moreover, other study concluded that blog offered online peer engagement (Mabuan, 2018). Other study also found that students' English language productivity increased using digital platforms (Nugroho \& Atmojo, 2020). Next, a study found that asynchronous peer feedback helped Taiwanese students in writing sentences (Shang, 2017). A study analyzed agriculture students' writing errors in an online environment (Prasetianto \& Maharddhika, 2020). In addition, teaching techniques in online learning have been proposed, such as online literature circle, cooperative learning, CAFÉ instructional design (Ferdiansyah et al., 2020; Ivone et al., 2020; Wang, 2020).

The previous studies that have been conducted focused on teaching techniques in online learning, the perception of primary school teachers and parents in online learning, and the students' engagement in online learning. Yet, studies hearing higher education teachers' and students' voices are still dearth of. Therefore, a present study was addressed to uncover grassroots voices in online learning. It is intriguing to hear grassroots voices since online learning has been applied for the first time in almost all parts of Indonesia. Grassroots in this present study refers to students and higher education teachers who are the users and the online learning doers. The significance of the present study can be used by policymakers as a basis in making online learning policy.

\section{Method}

The research setting was at the Faculty of Agriculture in one of the universities in East Java, Indonesia. The students received three types of learning, i.e., lecture, practicum, and tutorial. The lecture was that theoretical materials were delivered to students with a time allotment of one credit for 50 minutes. Practicum was that students practiced their skills and materials garnered from lectures with a time allotment of one credit for 100 minutes. The tutorial was to deepen and reinforce students' understanding of the materials through exercises and assignments. During the pandemic, the learning process must migrate into 
online, employing Google Classroom (GC) for asynchronous and Google Meet for synchronous learning. This present study recruited eight classes of the Agroecotechnology program from the Faculty of Agriculture in one of the universities in East Java, Indonesia. The participants were first-year students, and the total number of participants was 233 . The eight classes were chosen regarding their ease of access, and the researchers taught those classes. This research also involved 30 Agriculture teachers who agreed to participate in this research. They were senior, middle, and junior teachers from different programs at the Faculty of Agriculture. Senior teachers were defined as more than 20 years teaching, and middle teachers were more than 10 years teaching, junior teachers were less than ten years teaching.

The online questionnaire aimed to gain the students' and teachers' perceptions of GC during the COVID-19 pandemic. It consisted of seventeen questions for students and eighteen questions for the teachers. All items used Bahasa Indonesia and were rated on Likert-scale: strongly disagree (1-point), disagree (2-point), agree (3-point), and strongly agree (4-point). The questionnaires for students and teachers were classified into three indicators: ease of use, performance, and institution supports, with different questions tailored to each target participant. The questionnaires used Google form. A semi-structured interview was employed to garner in-depth data from the students and teachers. Ten questions were employed for the students and regarding their experience in using GC for online learning. The teachers' interview consisted of thirteen questions covering their prior experience in online teaching, the use of GC, giving online assessment and feedback, interaction with students, presenting materials, and the effectiveness of using GC for online teaching. The interview was conducted online through the Google Meet platform. During the interview, the researchers used Bahasa Indonesia to make the respondents ease responding to the questions. Sixteen out of thirty teachers were willingly interviewed and recorded. Meanwhile, 48 students were interviewed drawn from 6 representatives in each class.

Data was garnered from the questionnaires and the interviews. The questionnaires for both teachers and students were distributed through the Whatsapp group. The researchers randomly assigned six representatives from each class as interviewees and recorded the interviews for student interviews. The teachers who were willingly interviewed responded to the interview guides and recorded them. The average interview time for each student and teacher lasted around twenty to thirty minutes. The response of questionnaires was gained automatically since the questionnaires were distributed online using Google form. Then, the mean score of each question was estimated. The mean score was rounded up. Next, the data were interpreted descriptively. From the interview data, the recorded interviews were transcribed and translated into English. Then, the transcriptions were coded based on each theme. The research results portrayed the student and teacher perception of GC on three main themes: ease of use, performance, and institution support.

\section{Result and Discussion}

\section{Results}

The results of study are presented in two sections, i.e., students' voices and lecturers' voices. The students' and lecturers' voices are shown based on three indicators: ease of Google classroom, the performance of Google classroom, and institution supports.

\section{Students' Voices}

Students' voice was obtained from the questionnaires and interview. 233 students responded to the questionnaires. 47 students were willingly interviewed. The responses regarding the ease of using Google Classroom is presented in Table 1. Table 2 presents students' responses to performance of Google Classroom. Table 3 shows the students' responses to support provided by institution. 
Table 1. Responses to Ease of Using Google Classroom

\begin{tabular}{|c|c|c|c|}
\hline Question & Option & $f$ & mean \\
\hline $\begin{array}{l}\text { 1. It is easy to navigate features of } \\
\mathrm{GC}\end{array}$ & $\begin{array}{l}\text { SA } \\
\text { A } \\
\text { D } \\
\text { SD }\end{array}$ & $\begin{array}{l}76(32.6 \%) \\
152(65.2 \%) \\
5(2.1 \%) \\
0(0 \%)\end{array}$ & 3 \\
\hline 2. It easy to do the assignment & $\begin{array}{l}\text { SA } \\
\text { A } \\
\text { D } \\
\text { SD }\end{array}$ & $\begin{array}{l}43(18.5 \%) \\
161(69.1 \%) \\
27(11.6 \%) \\
2(0.9 \%)\end{array}$ & 3 \\
\hline 3. It is easy to submit assignment & $\begin{array}{l}\text { SA } \\
\text { A } \\
D \\
\text { SD }\end{array}$ & $\begin{array}{l}66(28.3 \%) \\
156(67 \%) \\
11(4.7 \%) \\
0(0 \%)\end{array}$ & 3 \\
\hline 4. It is easy to do a presentation & $\begin{array}{l}\text { SA } \\
\text { A } \\
D \\
\text { SD }\end{array}$ & $\begin{array}{l}30(12.9 \%) \\
128(54.9 \%) \\
70(30 \%) \\
5(2.1 \%)\end{array}$ & 3 \\
\hline $\begin{array}{l}\text { 5. It is easy to communicate or } \\
\text { discuss with teacher }\end{array}$ & $\begin{array}{l}\text { SA } \\
\text { A } \\
\text { D } \\
\text { SD }\end{array}$ & $\begin{array}{l}33(14.2 \%) \\
176(75.5 \%) \\
20(8.6 \%) \\
4(1.7 \%)\end{array}$ & 3 \\
\hline 6. It is easy to work individually & $\begin{array}{l}\text { SA } \\
\text { A } \\
D \\
\text { SD }\end{array}$ & $\begin{array}{l}42(18 \%) \\
168(72.1 \%) \\
20(8.6 \%) \\
3(1.3 \%)\end{array}$ & 3 \\
\hline 7. It is easy to work collaboratively & $\begin{array}{l}\text { SA } \\
\text { A } \\
D \\
\text { SD }\end{array}$ & $\begin{array}{l}14(6 \%) \\
139(59.7 \%) \\
75(32.2 \%) \\
5(2.1 \%)\end{array}$ & 2 \\
\hline $\begin{array}{l}\text { 8. It is easy to understand learning } \\
\text { material or teacher's explanation }\end{array}$ & $\begin{array}{l}\text { SA } \\
\text { A } \\
\text { D } \\
\text { SD }\end{array}$ & $\begin{array}{l}11(4.7 \%) \\
130(55.8 \%) \\
84(36.1 \%) \\
8(3.4 \%)\end{array}$ & 2 \\
\hline
\end{tabular}

Table 2. Responses to Performance of Google Classroom

\begin{tabular}{llll}
\hline \multicolumn{1}{c}{ Question } & Option & f & mean \\
\hline 1. GC has easy features to & SA & $35(15 \%)$ & 3 \\
understand & A & $179(76.8 \%)$ & \\
& D & $19(8.2 \%)$ & \\
2. GC provides ease of checking & SD & 0 & 3 \\
materials, assignments and & SA & $60(25.8 \%)$ & \\
announcement & D & $159(68.2 \%)$ & \\
& SD & $0(0 \%)$ & 3 \\
3. GC provides ease of saving & SA & $82(35.2 \%)$ & \\
materials and assignment and is & A & $145(62.2 \%)$ & \\
able to access them anytime & D & $6(2.6 \%)$ & 3 \\
& SD & $0(0 \%)$ & \\
4. GC provides to return score and & SA & $26(11.2 \%)$ & \\
feedback instantly & A & $168(72.1 \%)$ & $37(15.9 \%)$ \\
& D & $2(0.9 \%)$ & 3 \\
5. GC uses little memory space in & SA & $32(13.7 \%)$ &
\end{tabular}




\begin{tabular}{llll}
\hline \multicolumn{1}{c}{ Question } & Option & f & mean \\
\hline smartphone & A & $179(76.8 \%)$ & \\
& D & $21(9 \%)$ & \\
6. GC makes effective and efficient & SD & $1(0.4 \%)$ & 2 \\
learning & SA & $15(6.4 \%)$ & \\
& A & $124(53.2 \%)$ & \\
& D & $87(37.3 \%)$ & \\
& SD & $7(3 \%)$ & \\
\hline
\end{tabular}

Table 3. Responses to Supports Provided by Institution

\begin{tabular}{llll}
\hline \multicolumn{1}{c}{ Question } & \multicolumn{1}{c}{ Option } & \multicolumn{1}{c}{ f } & mean \\
\hline 1. Students undergo training on how & SA & $9(3.9 \%)$ & 2 \\
to use GC & A & $131(56.2 \%)$ & \\
& D & $83(35.6 \%)$ & \\
2. IT technician is ready to help for & SD & $10(4.3 \%)$ & 2 \\
technical problems & SA & $12(5.2 \%)$ & \\
& D & $141(60.5 \%)$ & \\
3. Students use internet data & SD & $5(2.1 \%)$ & \\
provided by the university & SA & $8(3.4 \%)$ & 2 \\
& A & $44(18.9 \%)$ & \\
& D & $96(41.2 \%)$ & \\
\hline
\end{tabular}

\section{Teachers' Voices}

Teachers' voice was obtained from the questionnaires and interviews. The questionnaires are presented in Table 4, elaborating on the ease of using Google Classroom. Thirty teachers responded to the questionnaires, and fifteen teachers were willingly interviewed. Table 5 shows the teachers' resposes to performance of Google Classroom. Table 6 presents the teachers' responses to supports provided by Institution.

Table 4. Responses to Ease of Using Google Classroom

\begin{tabular}{llll}
\hline \multicolumn{1}{c}{ Question } & \multicolumn{1}{c}{ Option } & mean \\
\hline 1. It is easy to navigate the features of GC & SA & $15(50 \%)$ & 3 \\
& A & $13(43.3 \%)$ & \\
& D & $2(6.7 \%)$ & \\
2. It is easy to prepare and compose & SD & $0(0 \%)$ & 3 \\
teaching materials & SA & $12(40 \%)$ & \\
& A & $16(53.3 \%)$ & \\
3. It is easy to assign a task & D & $2(6.7 \%)$ & 3 \\
& SD & $0(0 \%)$ & \\
& SA & $11(36.7 \%)$ & 3 \\
4. It is easy to categorize task and & A & $18(60 \%)$ & \\
assignment & D & $1(3.3 \%)$ & \\
& SD & $0(0 \%)$ & \\
5. It is easy to present teaching materials & SA & $11(36.7 \%)$ & 3 \\
& A & $12(40 \%)$ & \\
& D & $7(23.3 \%)$ & \\
& SD & $0(0 \%)$ & $11(36.7 \%)$ \\
& A & $17(56.7 \%)$ & 3 \\
& D & $2(6.7 \%)$ &
\end{tabular}




\begin{tabular}{llll}
\hline \multicolumn{1}{c}{ Question } & \multicolumn{1}{c}{ Option } & \multicolumn{1}{c}{ mean } \\
\hline 6. It is easy to communicate and discuss with & SA & $6(20 \%)$ & 3 \\
students & A & $19(63.3 \%)$ & \\
& D & $5(16.7 \%)$ & \\
7. It is easy to teach individually & SD & $0(0 \%)$ & 3 \\
& SA & $9(30 \%)$ & 3 \\
& A & $14(46.7 \%)$ & \\
8. It is easy to teach and work collaboratively & D & $7(23.3 \%)$ & \\
with other teachers & SD & $0(\%)$ & 3 \\
& A & $4(13.3 \%)$ & 3 \\
9. It is easy to access students' assignment & D & $20(66.7 \%)$ & \\
and score & SD & $1(16.7 \%)$ & \\
& SA & $8(26.3 \%)$ & 3 \\
& A & $17(56.7 \%)$ & \\
& D & $5(16.7 \%)$ & \\
\hline
\end{tabular}

Table 5. Responses to Performance of Google Classroom

\begin{tabular}{|c|c|c|c|}
\hline Question & Option & $f$ & mean \\
\hline \multirow[t]{4}{*}{ 1. GC has easy features to understand } & SA & $8(26.7 \%)$ & 3 \\
\hline & A & $21(70 \%)$ & \\
\hline & $\mathrm{D}$ & $1(3.3 \%)$ & \\
\hline & SD & $0(0 \%)$ & \\
\hline \multirow{4}{*}{$\begin{array}{l}\text { 2. GC provides ease of delivering materials, } \\
\text { assignments and announcement }\end{array}$} & SA & $15(50 \%)$ & 3 \\
\hline & A & $13(43.3 \%)$ & \\
\hline & D & $2(6.7 \%)$ & \\
\hline & SD & $0(0 \%)$ & \\
\hline 3. GC provides ease of saving materials and & SA & $12(40 \%)$ & 3 \\
\hline assignment and is able to access them & $A$ & $16(53.3 \%)$ & \\
\hline anytime & $\mathrm{D}$ & $2(6.7 \%)$ & \\
\hline & SD & $0(0 \%)$ & \\
\hline \multirow{4}{*}{$\begin{array}{l}\text { 4. GC facilitates teacher to assess, evaluate } \\
\text { and give feedback instantly }\end{array}$} & SA & $8(26.7 \%)$ & 3 \\
\hline & A & $19(63.3 \%)$ & \\
\hline & D & $3(10 \%)$ & \\
\hline & SD & $0(0 \%)$ & \\
\hline \multirow{4}{*}{$\begin{array}{l}\text { 5. GC uses little memory space in } \\
\text { smartphone }\end{array}$} & SA & $8(26.7 \%)$ & 3 \\
\hline & A & $14(46.7 \%)$ & \\
\hline & D & $8(26.7)$ & \\
\hline & SD & $0(0 \%)$ & \\
\hline \multirow[t]{4}{*}{ 6. GC makes effective and efficient learning } & SA & $6(20 \%)$ & 3 \\
\hline & $A$ & $16(53.3 \%)$ & \\
\hline & $\mathrm{D}$ & $8(26.7 \%)$ & \\
\hline & SD & $0(0 \%)$ & \\
\hline
\end{tabular}

Table 6. Responses to Supports Provided by Institution

\begin{tabular}{llll}
\hline \multicolumn{1}{c}{ Question } & \multicolumn{1}{c}{ Option } & \multicolumn{1}{c}{ f } & mean \\
\hline 1. Teachers undergo a training how to use & SA & $12(40 \%)$ & 3 \\
GC & A & $15(50 \%)$ & \\
& D & $3(10 \%)$ & \\
& SD & $0(0 \%)$ & \\
2. IT technician is ready to help for technical & SA & $8(26.7 \%)$ & 3 \\
problems & A & $20(66.7 \%)$ &
\end{tabular}




\begin{tabular}{llll}
\hline \multicolumn{1}{c}{ Question } & \multicolumn{1}{c}{ Option } & f & mean \\
\hline & D & $2(6.7 \%)$ & \\
3. Teacher uses internet data provided by & SD & $0(0 \%)$ & \\
the university & SA & $1(3.3 \%)$ & 2 \\
& A & $7(23.3 \%)$ & \\
& D & $16(53.3 \%)$ & \\
& SD & $6(20 \%)$ & \\
\hline
\end{tabular}

\section{Discussion \\ Students' Voices}

An easy feature of the online platform used is essential so that the teaching and learning process takes place. Students do not feel burden doing online activities such as assignments and quiz submission; one simple online platform is GC. GC had easy instructions to follow (Amin \& Sundari, 2020). Students are able to learn how to navigate the features by themselves. They learn from blogs or Youtube regarding how to use GC, even for a student who never used GC before.

Interaction with the teacher in the online platform must also be accommodated because the online platform enables students to ask if they need further clarification about the teaching materials. Learning is developed in student and teacher involvement (Mardiana, 2020). This involvement includes a question and answers interaction between teacherstudents or students-students. GC facilitated interaction between student and classroom content (Heggart \& Yoo, 2018). An excellent online platform should provide interaction in order learning experience takes place. GC accommodates this interaction with comment features, and it is asynchronous. Students feel beneficial in asynchronous interaction (Swaggerty \& Broemmel, 2017). In addition, collaborative work among students plays a pivotal role in learning. It was found that a positive relationship between interaction in the group and collaborative learning (Hernández-Sellés et al., 2019). Students' interaction among students when they are doing collaborative work affects their learning because they learn from their peers and fill a gap of knowledge. Yet, students view that GC less accommodate for collaboration. Students used Whatsapp for collaboration and interaction among them. Students prefer to use Whatsapp, which they often use. WhatsApp was two mostly phone use among students (Paakkari et al., 2019). Students' extent their use of technology by using other platform to support their learning if they think that a particular platform is insufficient.

One surprising result was that students were difficult to understand teaching materials. The teaching materials were only uploaded in GC, and then students read the materials. This type of teaching imitates in-class teaching in which students read the materials and then conduct a discussion led by the teacher. This type of teacher is the one who feels comfortable with his/her comfort zone in teaching and reluctant to improve their digital literacy (Mardiana, 2020). The teacher wants to explain in synchronous learning, whereas synchronous learning is challenged by the signal problem, resulting in a missing explanation. Asynchronous discussion is possibly a solution for comprehending materials in which the teacher explains further in the discussion. Also, their peer can contribute to the discussion regarding their perspective and trigger critical thinking. Peer-facilitation promotes critical thinking in asynchronous online discussion (Oh et al., 2018).

The online platform should be easily accessible for students in order they are able to check the assignment given by the teacher and saving the materials. Fortunately, GC provides notification of assignments to check and do not miss the assignment. Individuals with higher FOMO levels could have an increased chance of acquiring and engaging with more INs at the cost of other learning-related activities (Rozgonjuk et al., 2019). The notification is beneficial in online learning since students are flooded with several assignments from other different courses. Moreover, GC has a "to-do list" feature that can act as a reminder for students and review unfinished tasks. GC send the notification in students' email, then it will pop up in students' smartphone. Email notification increased students' participation in the virtual classroom (Morice et al., 2020). 
Online platform installed in a smartphone with low memory space enables increased accessibility and flexibility because students are really engaged with their smartphone. Ownership of a smartphone among Indonesian students is high (Pratama \& Scarlatos, 2020). With a high number of smartphone ownership, smartphones become students' personal belonging and are held everywhere. Hence, an online platform that can be accessed using a smartphone is preferable. GC was most satisfactory regarding device agnostic (Heggart \& Yoo, 2018). Students can access GC using their various devices, including smartphones.

\section{Teachers' Voice}

Online platform operationalized easily by the teacher is preferable. Teachers have many things to do when they teach, such as assigning tasks, preparing teaching materials, presenting the materials, and assessing the task. An easily operationalized platform saves the teacher's time to prepare what to teach during online teaching and learning. As teachers should be well-prepared to conduct online teaching (Mardiana, 2020b), time used for teaching preparation is more essential than used for technical problems in operating the online platform. Additionally, teachers apply efficient instructional methods and are selective during presenting the materials because of limited online learning time. Teachers modify materials and deliver essential materials (Fauzi \& Sastra Khusuma, 2020; Rasmitadila et al., 2020). Moreover, a good design of instruction plays a pivotal role in the success of technology-enhanced learning activities (Zheng et al., 2015). Teachers communicating with their students must be facilitated because of limited time in presenting materials synchronously. Teachers can trigger students' understanding of certain materials by posting a question. Questions posted facilitate students' discussion in the online platform, and thus the students can learn from their peers. The question posted is not yes/no question but a question inviting a longer response in order a discussion takes place. Divergent question prompts students' discussion because it invites a longer response from the students (Prasetianto, 2019).

Online platforms extremely help teachers regarding assignments because they easily access the scores everywhere, without bringing students' paperwork everywhere. The scores are organized based on the assignment, and they can be downloaded. Moreover, the lost possibility of students' work is minimized since the work is uploaded in the cloud. It is sometimes difficult to manage students' work for the teacher having several classes with many students in each class. Thus, online learning reduces the teacher's workload related to the assignment. The online platform used offers simple features for teachers; thus, they are able to understand the function of the features. Some of the simple features are delivering materials, assignments, and assessments. Those features are required by teachers when they teach in-class teaching activities. The online platform enables teachers to adapt instantly using it. As e-learning or technology-related application becomes an obstacle for several teachers (Windiarti et al., 2019). Therefore, the online platform providing easy features is preferable.

An assessment using the online platform is efficiently conducted because the score emerges automatically. It helps teachers a lot because assessing students' tasks is timeconsuming and energy-consuming, especially a large class. Although the teaching and learning process was conducted online, teachers expressed a positive view of learning effectiveness and efficiency. It means that learning objectives can be obtained through online learning. The learning outcome is achieved during online learning (Giatman et al., 2020). Supports from other parties are also required because the sudden shift in education needs collaboration from several parties, e.g. teachers, institutions, and governments. Online learning-related training provided by the institution is helpful in order to increase teachers' skills in technology. As previous study suggested that training and guidance from IT experts were needed (Windiarti et al., 2019). 


\section{Conclusions and Suggestions}

Teachers' and students' views on online learning are positive. Their positive impression comes from the ease of the online platform operation, the online platform's good performance, but student views that the institutional support is not maximally implemented. The ease of using online platforms should be considered in choosing one of the various online platforms available. The online platform features are not complicated for students and teachers to easily operationalize the online platform and support teaching and learning activities such as delivering materials, assigning tasks, submitting a task, and assessing tasks. Furthermore, other parties support, e.g., institutions and governments are required in order the teaching and learning activities are conducted well in the online environment. The present study has limitations because it employed students from a similar study program and a similar cohort. Further research needs to conduct. The research employs more students and teachers, e.g., students with different cohorts. A research hearing from a policymaker's perspective is interesting to conduct.

\section{Acknowledgements}

PNBP of Faculty of Agriculture, Brawijaya University funded this research under contract number 2448/UN10.F04/PN/2020. We would like to thank our research assistants, who have helped us. We also would like to thank our participants.

\section{References}

Amin, F. M., \& Sundari, H. (2020). EFL students' preferences on digital platforms during emergency remote teaching: Video conference, Ims, or messenger application? Studies in English Language and Education, 7(2), 362-378. https://doi.org/10.24815/siele.v7i2.16929.

Atmojo, A. E. P., \& Nugroho, A. (2020). EFL Classes Must Go Online! Teaching Activities and Challenges during COVID-19 Pandemic in Indonesia. Register Journal, 13(1), 49-76. https://doi.org/10.18326/rgt.v13i1.49-76.

Fauzi, I., \& Sastra Khusuma, I. H. (2020). Teachers' Elementary School in Online Learning of COVID-19 Pandemic Conditions. Jurnal Iqra': Kajian IImu Pendidikan, 5(1), 58-70. https://doi.org/10.25217/ji.v5i1.914.

Ferdiansyah, S., Ridho, M. A., Sembilan, F. D., Sembilan, F. D., \& Zahro, S. F. (2020). Online literature circles during the COVID-19 pandemic: Engaging undergraduate students in Indonesia. TESOL Journal, 11(3). https://doi.org/10.1002/tesj.544.

Giatman, M., Siswati, S., \& Basri, I. Y. (2020). Online learning quality control in the pandemic Covid-19 era in Indonesia. Journal of Nonformal Education, 6(2), 168-175. https://journal.unnes.ac.id/nju/index.php/jne/article/view/25594.

Heggart, K. R., \& Yoo, J. (2018). Getting the most from google classroom: A pedagogical framework for tertiary educators. Australian Journal of Teacher Education, 43(3), 140-153. https://doi.org/10.14221/ajte.2018v43n3.9.

Hernández-Sellés, N., Pablo-César Muñoz-Carril, \& González-Sanmamed, M. (2019). Computer-supported collaborative learning: An analysis of the relationship between interaction, emotional support and online collaborative tools. Computers and Education, 138, 1-12. https://doi.org/10.1016/j.compedu.2019.04.012.

Ivone, F. M., Jacobs, G. M., \& Renandya, W. A. (2020). Far Apart, Yet Close Together: Cooperative Learning in Online Education. Studies in English Language and Education, 7(2), 271-289.

$\mathrm{Ke}, \mathrm{F}$. (2013). Online interaction arrangements on quality of online interactions performed by diverse learners across disciplines. Internet and Higher Education, 16(1), 14-22. https://doi.org/10.1016/j.iheduc.2012.07.003.

Limbu, L., \& Markauskaite, L. (2015). How do learners experience joint writing: University students' conceptions of online collaborative writing tasks and environments. 


$$
\text { Computers and Education, 82, 393-408. }
$$

https://doi.org/10.1016/j.compedu.2014.11.024.

Mabuan, R. A. (2018). Using Blogs in Teaching Tertiary Esl Writing. English Review: Journal of English Education, 6(2), 1. https://doi.org/10.25134/erjee.v6i2.1238.

Mardiana, H. (2020). Lecturers' Adaptability To Technological Change And Its Impact On The Teaching Process. JPI (Jurnal Pendidikan Indonesia), 9(2), 275-289. https://doi.org/10.23887/jpi-undiksha.v9i2.24595.

Milošević, I., Živković, D., Arsić, S., \& Manasijević, D. (2015). Facebook as virtual classroom - Social networking in learning and teaching among Serbian students. Telematics and Informatics, 32(4), 576-585. https://doi.org/10.1016/j.tele.2015.02.003.

Morice, A., Jablon, E., Delevaque, C., Hossein Khonsari, R., Picard, A., \& Kadlub, N. (2020). Virtual versus traditional classroom on facial traumatology learning: Evaluation of medical student's knowledge acquisition and satisfaction. Journal of Stomatology, Oral and Maxillofacial Surgery, 1-4. https://doi.org/10.1016/j.jormas.2020.03.001.

Neumann, K. L., \& Kopcha, T. J. (2019). Using Google Docs for Peer-then-Teacher Review on Middle School Students' Writing. Computers and Composition, 54, 102524. https://doi.org/10.1016/j.compcom.2019.102524.

Nugroho, A. ., \& Atmojo, A. E. P. (2020). Digital Learning Of English Beyond Classroom: Efl Learners' Perception And Teaching Activities. JEELS, 7(2), 219-243.

Oh, E. G., Huang, W. H. D., Hedayati Mehdiabadi, A., \& Ju, B. (2018). Facilitating critical thinking in asynchronous online discussion: comparison between peer- and instructor-redirection. Journal of Computing in Higher Education, 30(3), 489-509. https://doi.org/10.1007/s12528-018-9180-6.

Paakkari, A., Rautio, P., \& Valasmo, V. (2019). Digital labour in school: Smartphones and their consequences in classrooms. Learning, Culture and Social Interaction, 21, 161169. https://doi.org/10.1016/j.Icsi.2019.03.004.

Prasetianto, M. (2019). Kinds of Questions Making EFL Students Learn: Students' Perception. JOALL (Journal of Applied Linguistics \& Literature), 4(2), 162-176. https://doi.org/10.33369/joall.v4i2.7607.

Prasetianto, M., \& Maharddhika, R. (2020). Online Writing Exchange with Overseas Students: EFL Learners' Errors and Perceptions. Elite Journal, 7(1), 74-86.

Pratama, A. R., \& Scarlatos, L. L. (2020). Ownership and Use of Mobile Devices Among Adolescents in Indonesia. Journal of Educational Technology Systems, 48(3), 356384. https://doi.org/10.1177/0047239519886584.

Purwanto, A., Pramono, R., Asbari, M., Santoso, P. B., Wijayanti, L. M., Hyun, C. C., \& Putri, R. S. (2020). Exploratory Study of the Impact COVID-19 Pandemic on Online Learning Process in Primary Schools. Jurnal Kesehatan Lingkungan, 2(1), 129-136. https://doi.org/10.20473/jkl.v12i1si.2020.129-136.

Rasmitadila, R., Aliyyah, R. R., Rachmadtullah, R., Samsudin, A., Syaodih, E., Nurtanto, M., \& Tambunan, A. R. S. (2020). The Perceptions of Primary School Teachers of Online Learning during the COVID-19 Pandemic Period: A Case Study in Indonesia. Journal of Ethnic and Cultural Studies, 7(2), 90. https://doi.org/10.29333/ejecs/388.

Rozgonjuk, D., Elhai, J. D., Ryan, T., \& Scott, G. G. (2019). Fear of missing out is associated with disrupted activities from receiving smartphone notifications and surface learning in college students. Computers and Education, 140(March), 103590. https://doi.org/10.1016/j.compedu.2019.05.016.

Ruthotto, I., Kreth, Q., Stevens, J., Trively, C., \& Melkers, J. (2020). Lurking and participation in the virtual classroom: The effects of gender, race, and age among graduate students in computer science. Computers and Education, 151(February). https://doi.org/10.1016/j.compedu.2020.103854.

Shang, H. F. (2017). An exploration of asynchronous and synchronous feedback modes in EFL writing. Journal of Computing in Higher Education, 29(3), 496-513. https://doi.org/10.1007/s12528-017-9154-0.

Shu, H., \& Gu, X. (2018). Determining the differences between online and face-to-face student-group interactions in a blended learning course. Internet and Higher 
Education, 39(November 2017), 13-21. https://doi.org/10.1016/j.iheduc.2018.05.003.

Straub, C., \& Vasquez, E. (2016). Effects of Synchronous Online Writing Instruction for Students With Learning Disabilities. Journal of Special Education Technology, 30(4), 213-222. https://doi.org/10.1177/0162643415618929.

Swaggerty, E. A., \& Broemmel, A. D. (2017). Authenticity, relevance, and connectedness: Graduate students' learning preferences and experiences in an online reading education course. Internet and Higher Education, 32, 80-86. https://doi.org/10.1016/j.iheduc.2016.10.002.

Ulla, M. B., \& Perales, W. F. (2020). The adoption of Facebook as a virtual class whiteboard: Promoting EFL students' engagement in language tasks. TESOL Journal, 1-4. https://doi.org/10.1002/tesj.515.

Valencia-Arias, A., Chalela-Naffah, S., \& Bermúdez-Hernández, J. (2019). A proposed model of e-learning tools acceptance among university students in developing countries. Education and Information Technologies, 24(2), 1057-1071. https://doi.org/10.1007/s10639-018-9815-2.

Wang, C. X. (2020). CAFE: An Instructional Design Model to Assist K-12 Teachers to Teach Remotely during and beyond the Covid-19 Pandemic. TechTrends. https://doi.org/10.1007/s11528-020-00555-8.

Windiarti, S., Fadilah, N., Dhermawati, E., \& Pratolo, B. W. (2019). Teachers' Perception toward the Obstacles of E-Learning Classes. Ethical Lingua: Journal of Language Teaching and Literature, 6(2), 117-128. https://doi.org/10.30605/25409190.v6.117128.

Yi, Y., \& Jang, J. (2020). Envisioning possibilities amid the COVID-19 pandemic: Implications from English language teaching in South Korea. TESOL Journal, 11(3), 1-5. https://doi.org/10.1002/tesj.543.

Zheng, B., Niiya, M., \& Warschauer, M. (2015). Wikis and collaborative learning in higher education. Technology, Pedagogy and Education, 24(3), 357-374. https://doi.org/10.1080/1475939X.2014.948041.

Zheng, B., \& Warschauer, M. (2015). Participation, interaction, and academic achievement in an online discussion environment. Computers and Education, 84, 78-89. https://doi.org/10.1016/j.compedu.2015.01.008. 